\title{
SERBIAN TERTIARY ULTRAPOTASSIC PROVINCE-PETROLOGY, GEOCHEMISTRY AND GEODYNAMIC SIGNIFICANCE
}

\author{
Dejan Prelevic ${ }^{1}$, Stephen F. Foley ${ }^{1}$, Rolf Romer $^{2}$ and Vladica Cvetkovic ${ }^{3}$ \\ ${ }^{1}$ Universität Greifswald, Germany; ${ }^{2}$ GFZ Potsdam, Germany; ${ }^{3}$ University of Belgrade, Yugoslavia
}

\section{INTRODUCTION}

Serbian Tertiary ultrapotassic province is the third European ultrapotassic province, together with Italian and Spanish counterparts. It comprises a spectrum of ultrapotassic rocks with contrasting geodynamic provenance occurring in a restricted area. It is related to the post-collisional tectonic regime after the end of Mesozoic subduction events.

Our results suggest that Serbian ultrapotassic magmatism is related to the melting of heterogeneously metasomatized lithospheric mantle in accordance with the geological situation in Serbia, which is a complex collage of different small and jumbled microcontinents with different histories, finally merged together during Alpine orogenesis. We found that central Serbian zone (the Vardar zone) has been the most productive source of ultrapotassic melts derived from a veined mantle source with metasomatic veins made up of nonperidotitic assemblage comprising phlogopite and apatite. The volcanics from the westernmost block indicate that metasomatic assemblage is here homogeneously disseminated and represented by phlogopite, Ti-oxide and apatite.

\section{PETROGRAPHY AND GEOCHEMISTRY}

Two groups of ultrapotassic (UP) rocks are recognized. The lamproite affinity group (LAG) is remarkably heterogeneous suite comprising phlogopite-lamproites ( $\mathrm{SiO}_{2}$-rich lamproites) and related rocks. They are slightly undersaturated, having $\mathrm{SiO}_{2}$ around $50 \mathrm{wt} \%$,

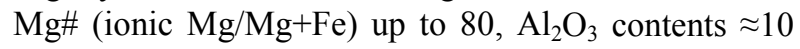
wt $\%$ and $\mathrm{Cr} 800 \mathrm{ppm}$ and $\mathrm{Ni} 500$ ppm in the most primitive samples. They are extremely enriched in LILE with high LILE/HFSE ratios (>5000 x PM for Cs and up to $800 \times \mathrm{PM}$ for $\mathrm{Th}$ and $\mathrm{U}$ ), and have high LILE/HFSE ratios, troughs at $\mathrm{Nb}-\mathrm{Ti}$ and $\mathrm{P}$, peaks at $\mathrm{Pb}$ and ubiquitous $\mathrm{Eu}$ negative anomaly, clearly resembling Mediterranean-type lamproites (Venturelli et al., 1984a; Venturelli et al., 1984b; Conticelli, 1998; Conticelli et al., 2002).

The kamafugite affinity group (KAG) rocks encompass olivine-leucitites (ugandites), leucite-basanites and

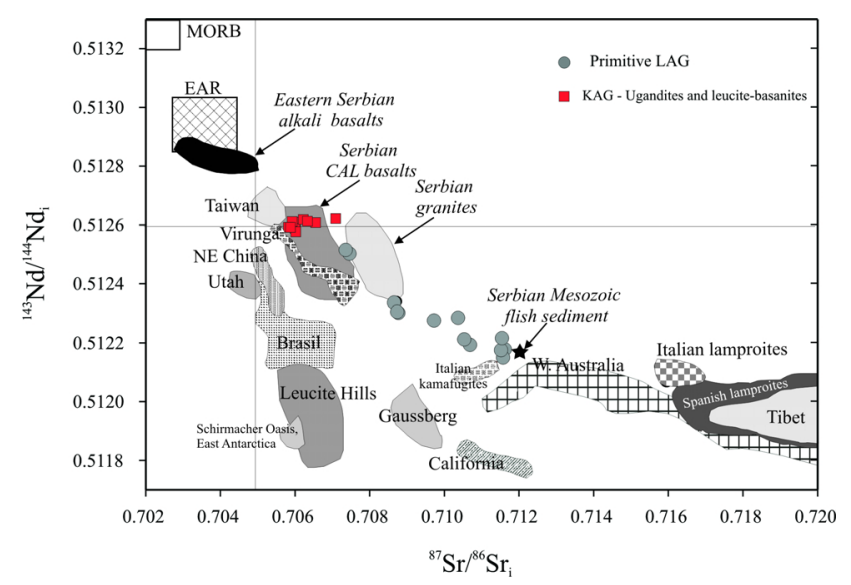

Figure 1 - The $\mathrm{Sr}-\mathrm{Nd}$ isotopic systematic of Serbian ultrapotassic rocks.

ankaratrites, sometimes with very high $\mathrm{CaO}$ content (up to $14 \mathrm{wt} \%$ ). Most KAG rocks are ultrabasic (as low as $42 \% \mathrm{SiO}_{2}$ ), showing a wide range of abundances of compatible elements (200-503 ppm Cr, 160-322 ppm $\mathrm{Ni}$. Incompatible elements display similar patterns to LAG rocks, but with a less pronounced LILE/HFSE enrichment. The trough at $\mathrm{P}$ and differences in $\mathrm{Nb} / \mathrm{Zr}$ ratio (0.08-0.16) indicate the role of apatite and $\mathrm{Ti}$ oxide, respectively. Chondrite-normalized REE patterns for KAG-rocks show gradual increase in the level of fractionation indicating that it is controlled by different partial melting process.

The spatial separation of the two Serbian ultrapotassic suites and their restriction to different geotectonic units is an exceptional feature of this volcanism. The LAG rocks are concentrated within the Vardar zone that is the main suture zone of the Balkan Peninsula, with only one exception (Bogovina locality situated in the East Serbian composite terrane to the east). On the other hand, KAG rocks occur exclusively in the western (Dinarides and Drina-Ivanjica) terranes.

The most noticeable feature of the radiogenic isotopic signature of Serbian ultrapotassic rocks is a wide range of $\mathrm{Sr}$ and $\mathrm{Nd}$ isotopic values (Fig. 1) with a restricted variation of $\mathrm{Pb}$ isotopes (Fig. 2), similarly to other Mediterranean ultrapotassic provinces (Nelson et al., 1986; Nelson, 1992; Conticelli et al., 2002).

The primitive LAG-samples (>70 Mg\#, high $\mathrm{Cr}$ and $\mathrm{Ni}$ ) plot in the mantle-array, clearly trending towards 


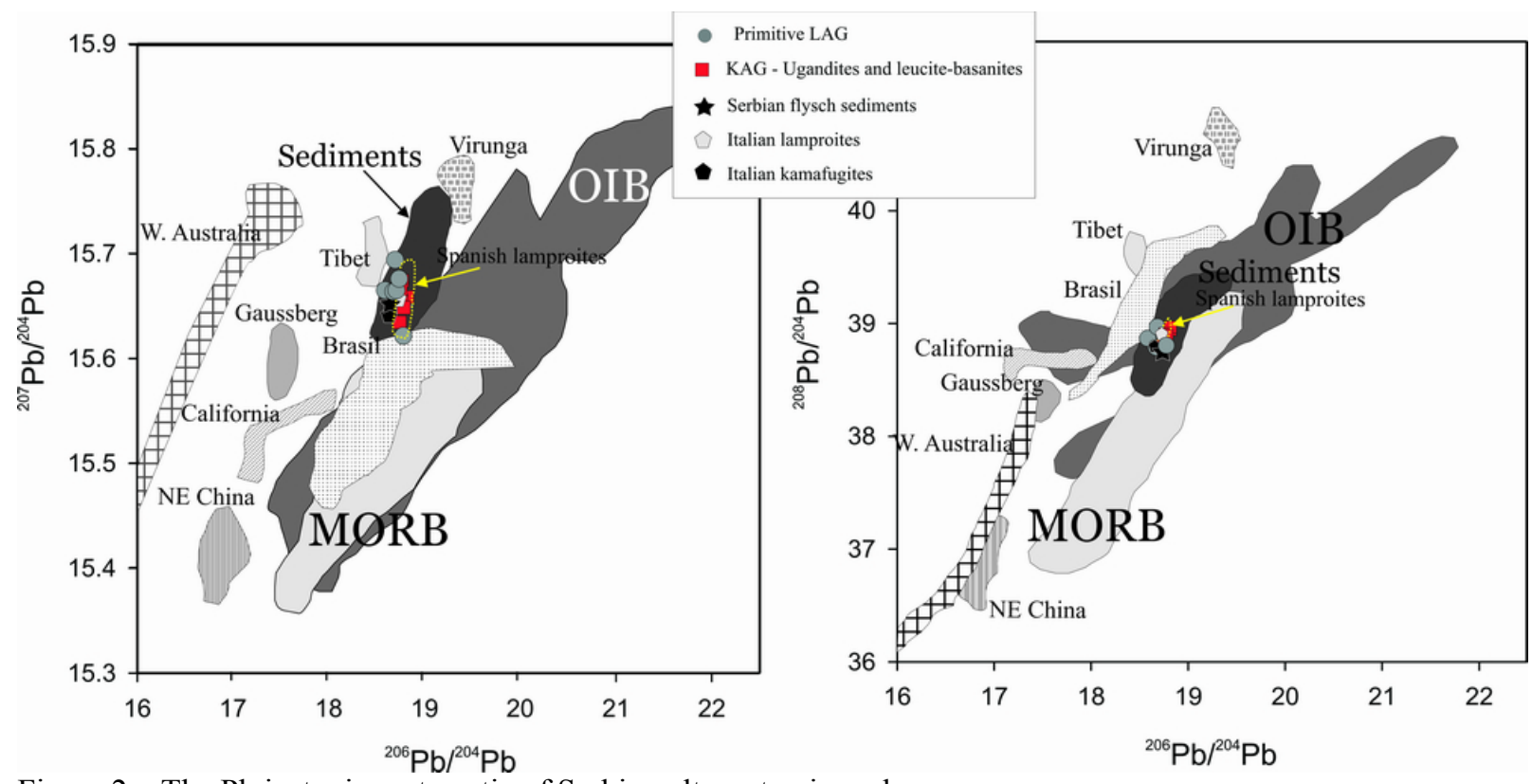

Figure 2 - The $\mathrm{Pb}$ isotopic systematic of Serbian ultrapotassic rocks

crustal-like ${ }^{87} \mathrm{Sr} /{ }^{86} \mathrm{Sr}$ vs ${ }^{143} \mathrm{Nd} /{ }^{144} \mathrm{Nd}$ space. In contrast to LAG, primitive KAG samples (>70 Mg\#, high $\mathrm{Cr}$ and $\mathrm{Ni})$ display relatively uniform $\mathrm{Sr}$ and $\mathrm{Nd}$ isotopic data. In contrast to wide variations of ${ }^{87} \mathrm{Sr} /{ }^{86} \mathrm{Sr}$ and ${ }^{143} \mathrm{Nd} /{ }^{144} \mathrm{Nd}, \mathrm{Pb}$ isotopes of all Serbian ultrapotassic rocks display uniform ${ }^{206} \mathrm{~Pb} /{ }^{204} \mathrm{~Pb}$ but some variation in ${ }^{207} \mathrm{~Pb} /{ }^{204} \mathrm{~Pb}$ and ${ }^{208} \mathrm{~Pb} /{ }^{204} \mathrm{~Pb}$ (Fig. 2). They plot above depleted mantle line on ${ }^{206} \mathrm{~Pb} /{ }^{204} \mathrm{~Pb}$ vs ${ }^{207} \mathrm{~Pb} /{ }^{204} \mathrm{~Pb}$ and ${ }^{208} \mathrm{~Pb} /{ }^{204} \mathrm{~Pb}$ diagrams in Figure 2 and fall within the pelagic sediment field (Ben Othman et al., 1989). The Mesozoic flysch sediments from the central Serbian suture zone (Vardar), show an excellent isotopic resemblance (Fig. 2).

\section{MANTLE SOURCE CONSTRAINTS}

$\mathrm{The} \mathrm{Sr} / \mathrm{Nd}$ isotopic systematics together with the trace element distributions of the most-primitive noncumulitic rocks, lend support to the idea that two Serbian ultrapotassic suites came from different mantle sources. On the other hand, the excellent agreement between the $\mathrm{Pb}$ isotopic signature of Mesozoic flysch sediments and Serbian ultrapotassic rocks is a strong argument for metasomatism via subduction of sedimentary rocks. We interpret differences in behavior of the two suites in the $\mathrm{Sr}$ and $\mathrm{Nd}$ isotopic systems as depending upon the melting process and the type of crustal material that metasomatized their mantle source.

\section{LAG-ROCKS}

$\mathrm{Sr} / \mathrm{Nd} / \mathrm{Pb}$ isotopic variation and HFSE ratios of primitive LAG rocks, together with different levels of incompatible-element enrichment, are produced by the vein+wall-rock melting process. Their $\mathrm{Sr}-\mathrm{Nd}$ and $\mathrm{Pb}$ isotopic variation correspond to modelled mixing array between a depleted MORB-like mantle melt and a veinderived melt (Fig. 3) endowed with a highly radiogenic $\mathrm{Sr}$ and $\mathrm{Pb}$ and unradiogenic $\mathrm{Nd}$ isotope signature resembling local crust (flysch sediments). Large range of $\mathrm{Sr}$ and $\mathrm{Nd}$ isotopic values contrasts to very restricted variations of $\mathrm{Pb}$ isotopes. It is expected because the $\mathrm{Pb}$ isotopic composition is dominated by the vein-derived end-member, due to its considerably higher $\mathrm{Pb}$ concentration than in the MORB-melt. The behavior of HFSE and their ratios are in line with isotopic systematics (Fig. 3), with the most enriched endmember showing the highest $\mathrm{La} / \mathrm{Lu}, \mathrm{La} / \mathrm{Yb}$ ratios and $\mathrm{TiO}_{2}$ and $\mathrm{Nb}$ abundances (Fig. 3). Moreover, mineral chemistry of primitive-LAG rocks also vary according to the proposed model, with the most refractory composition of $\mathrm{Cr}$-spinels ( $\mathrm{Cr} \#$ up to 0.95 ) and the lowest $\mathrm{TiO}_{2}$ content in $\mathrm{Cpx}$ in the samples showing the highest degree of hybridization. Results of isotope and trace-element modelling are all in consistence with up to $80 \%$ of mixing between the end-members.

The exception to above model is observed in Bogovina lavas, the easternmost LAG locality (Fig. 3). They demonstrate highly fractionated REE patterns with HREE $<10 \mathrm{x}$ chondrite, presumably indicating the 

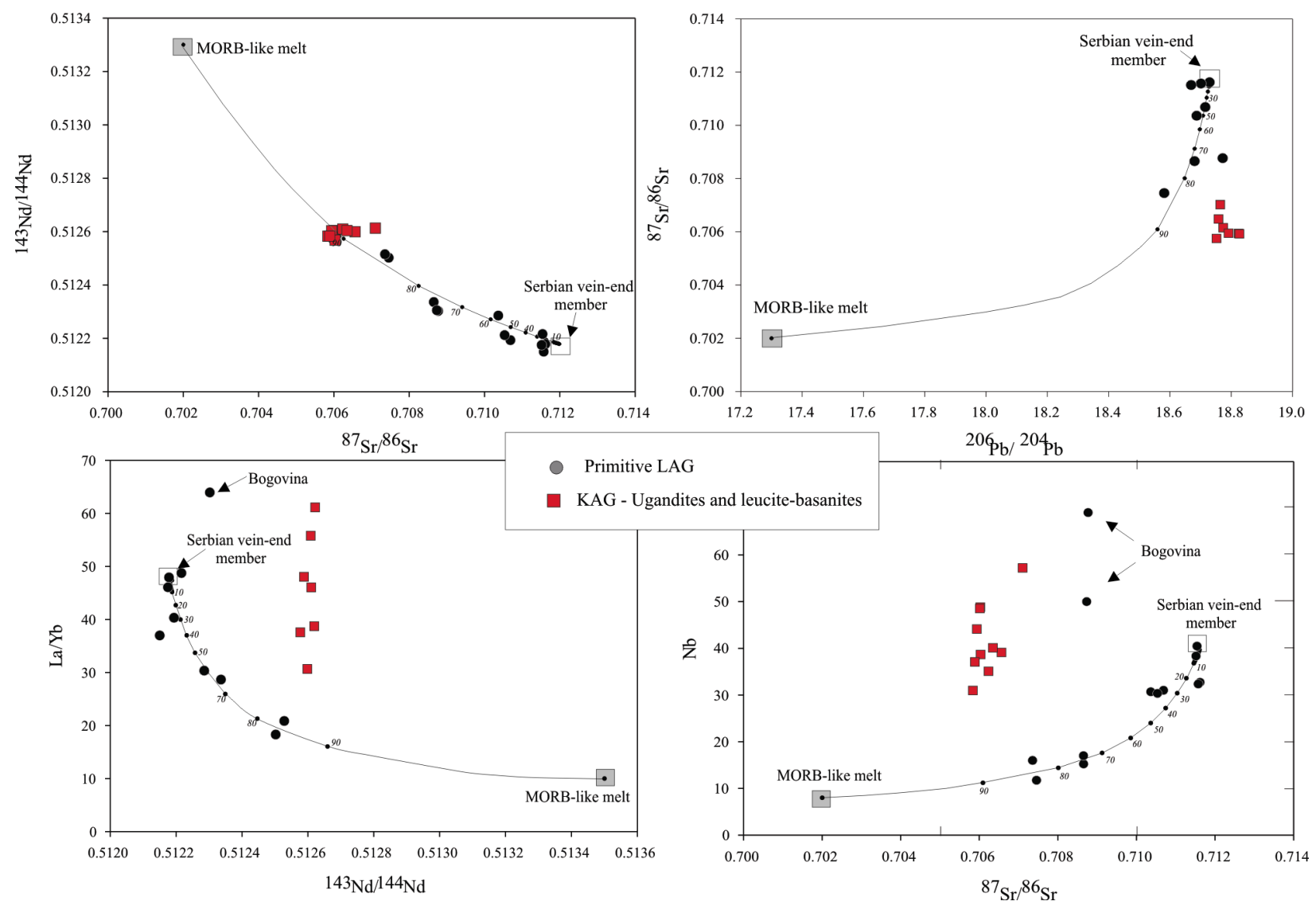

Figure 3 - Isotopic and trace-element modeling of Serbian ultrapotassic rocks.

presence of residual garnet in the source region. These features are not observed in other LAG-rocks.

The major and trace element (high $\mathrm{K}_{2} \mathrm{O} / \mathrm{Na}_{2} \mathrm{O}$ ratio, $\mathrm{P}$ troughs) show that the most reasonable mineralogy of the veins should be consisted of phlogopite+apatite.

\section{KAG-ROCKS}

Limited isotopic variability of the primitive KAGrocks, implies a homogeneous source composition, relative to the scale of melting. $\mathrm{Sr} / \mathrm{Nd} / \mathrm{Pb}$ systematics indicate that the KAG-lavas are derived from the source which is, like for the LAG-rocks, dominantly metasomatized with a crustal-like $\mathrm{Pb}$ signature. However, the samples are characterized by more radiogenic $\mathrm{Sr}$ and unradiogenic $\mathrm{Nd}$ isotope ratios. This isotopic variation may lend support for involvement of metasomatic input of considerably different crustal material than for the LAG-rocks. The most reasonable candidates might be oceanic biogenic sediments including calcareous and siliceous sediments with a significant clay fraction (Ben Othman et al., 1989).

Amphibole and phlogopite are phases usually considered to be stable in the Upper-mantle, hosting water and LILE in metasomatized peridotitic mantle (Luth et al., 1993). Given the ultrapotassic character of
KAG-rocks, phlogopite and K-richterite are two reasonable candidates for the $\mathrm{K}$-host in their mantle source. We argue that phlogopite is most likely to be in the source of KAG-rocks because of their generally low $\mathrm{SiO}_{2}$ contents that would have been much higher in case of melting of K-richterite bearing peridotite. It is to be expected because of the elimination of K-richterite as soon as the solidus is crossed (Foley et al., 1999; Konzett and Ulmer, 1999). Moreover, P-troughs at and differences in $\mathrm{Nb} / \mathrm{Zr}$ ratio in the most primitive KAGrocks may be explained by the role of apatite and Tioxide in the mantle source.

\section{GEODYNAMIC MODEL}

After the closure of the last Tethyan Oceanic domain in the Upper Cretaceous/Paleocene, the Dinaride part of the Alpides became an area of post-collision/relaxation tectonics. The gravitational collapse of the Dinaride orogen is inferred from fault patterns and shape, and the sedimentary record of lacustrine basins (Fig. 4). This geodynamic event could have initiated Serbian UP magmatism in response to two controlling factors which most likely operated concomitantly: (1) the stability of the Thermal Boundary Layer (TBL) beneath the Dinarides reached its critical point and (2) the 
organization of the adjacent terranes caused a change of principal stress orientation. Both events caused convective removal of the lithospheric root and melting of different mantle materials. This mantle dynamics provided conditions for partial melting of variously metasomatized lithospheric-mantle domains.

The geochemistry of Serbian UP rocks suggests that the metasomatism itself is most likely related to Mesozoic subduction events. During the subsequent lithospheric convective thinning and advection in the region of the TBL, these enriched lithospheric domains are exposed to the hot asthenosphere, giving rise to melting. Our results suggest zonation of metasomatic assemblages in the Serbian lithospheric upper-mantle. For LAG rocks, a phlogopite-bearing refractory spinel harzburgite (Central Serbia) and garnet-harzburgite (Easternmost LAG-rocks) source with phlogopite and apatite situated in the veins is most probable. The metasomatic assemblage for KAG source consisted of phlogopite, apatite and Ti-oxides could be homogeneously disseminated through mantle peridotite.
The presence of two ultrapotassic suites in a restricted space is attributable to the complex geodynamic situation involving many microcontinents with different histories and recording variable metasomatic imprints. It implies that the mantle dynamics included melting of variously metasomatized, shallower lithospheric mantle, excluding the role of sublithospheric mantle source. Our interpretation is that there is no need for any kind of sublithospheric controlled mechanisms including mantle plume, for the origin of Serbian ultrapotassic volcanism. The general geodynamic of the region with many extensional episodes and its surface exposure recorded in the pull-apart basins and lacustrine provinces (Djurdjevic, 1992; Obradovic et al., 1994; Marovic, 1998; Marovic et al., 1999; Marovic et al., 2000; Marovic et al., 2001) hold together at the regional and local levels with the ultrapotassic occurrences, providing straightforward relationship between geodynamics and volcanism.

\section{COLLAPSE OF DINARIC OROGEN AND UP VOLCANISM IN RESPONSE TO CONVECTIONAL REMOVAL OF LITHOSPHERIC MANTLE}

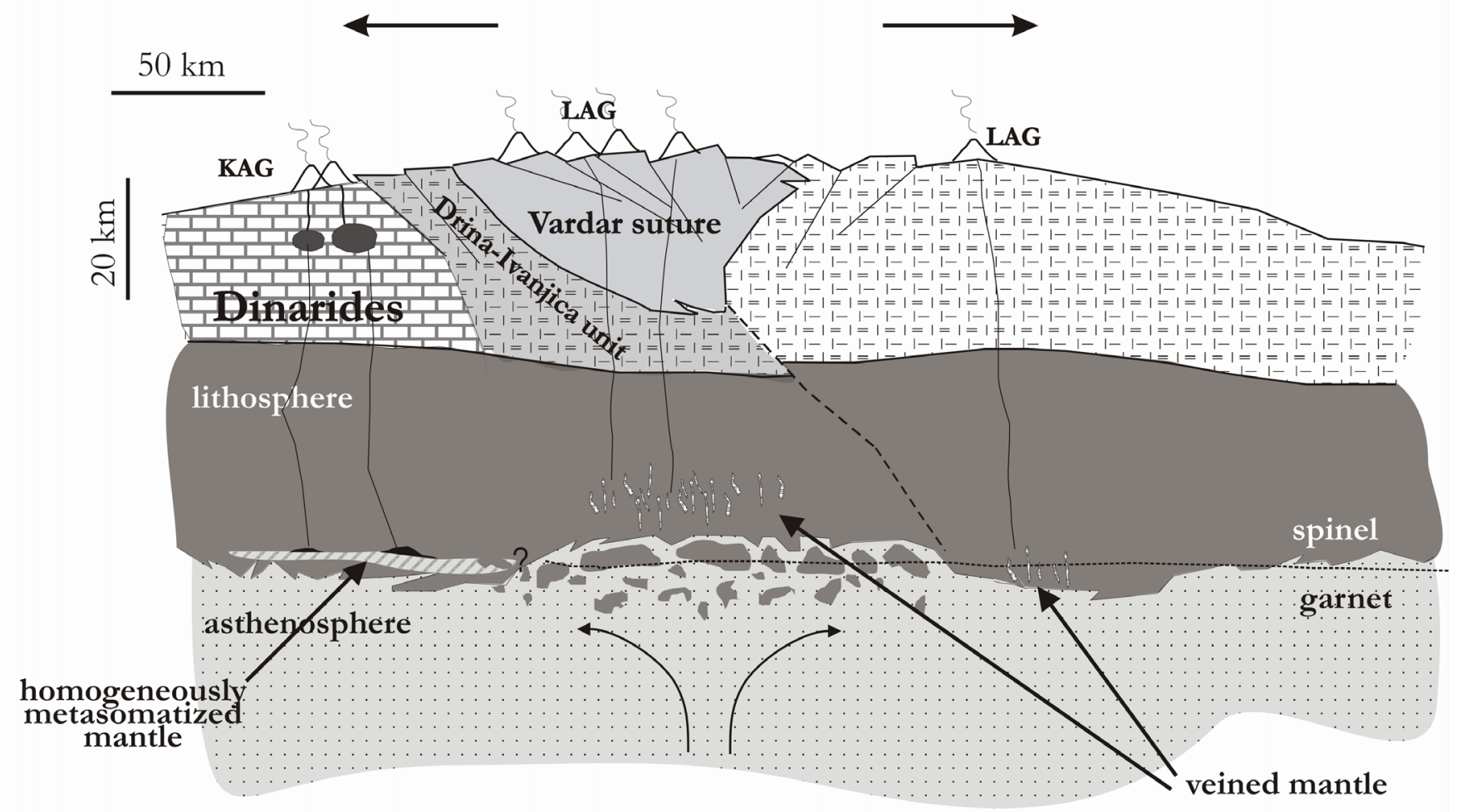

Figure 4 - Geodynamic model of the origin of Serbian ultrapotassic magmatism. 


\section{REFERENCES}

Ben Othman, D., White, W.M. and Patchett, J., 1989. The geochemistry of marine sediments, island arc magma genesis, and crust-mantle recycling. Earth and Planetary Science Letters, 94(1-2): 1-21.

Conticelli, S., 1998. The effect of crustal contamination on ultrapotassic magmas with lamproitic affinity: mineralogical, geochemical and isotope data from the Torre Alfina lavas and xenoliths, Central Italy. Chemical Geology, 149: 51-81.

Conticelli, S., D'Antonio, M., Pinarelli, L. and Civetta, L., 2002. Source contamination and mantle heterogeneity in the genesis of Italian potassic and ultrapotassic volcanic rocks: $\mathrm{Sr}-\mathrm{Nd}-\mathrm{Pb}$ isotope data from Roman Province and Southern Tuscany. Mineralogy and Petrology, 74(2-4): 189-222.

Djurdjevic, J., 1992. Sedimentology of the neogene lake basins, on the example of the Pranjani basin. MSc Thesis, University of Belgrade, Belgrade, $193 \mathrm{pp}$.

Foley, S.F., Musselwhite, D.S. and van der Laan, S.R., 1999. Melt compositions from ultramafic vein assemblages in the lithospheric mantle; a comparison of cratonic and non-cratonic settings, The J B Dawson volume; proceedings of the VIIth international kimberlite conference; Volume 1, United States, pp. 238-246.

Konzett, J. and Ulmer, P., 1999. The Stability of Hydrous Potassic Phases in Lherzolitic Mantle - an Experimental Study to $9.5 \mathrm{GPa}$ in Simplified and Natural Bulk Compositions. Journal of Petrology, 40: 629-652.

Luth, R.W., Tronnes, R.G. and Canil, D., 1993. Volatilebearing phases in the Earth's mantle, Short course handbook on experiments at high pressure and applications to the Earth's mantle. Mineralogical Association of Canada, [Toronto, ON], Canada, pp. 445-485.

Marovic, M., Krstic, N., Stanic, S., Cvetkovic, V. and Petrovic, M., 1999. The evolution of Neogene sedimentation provinces of Central Balkan Peninsula. Bulletin of Geoinstitut, 36: 25-94.

Marovic, M., Dokovic, I., Pesic, L., Toljic, M. and Gerzina, N., 2000. The genesis and geodynamics of Cenozoic sedimentation provinces of the central Balkan Peninsula. Geotectonics, 34(5): 415-427.

Marovic, M., Mihailovic, D., Djokovic, I., Gerzina, N. and Toljic, M., 2001. Wrench tectonic of the PaleogeneLower basins of Serbia between the central part of the Vardar Zone and the Moesian Plate. PANCARDI 2001, Sopron, Abstracts.

Marovic, M., Djokovic, I., Toljic, M., 1998. Genesis of the Neotectonic Structures of Serbia. Ann. Géol. Pénins. Balk., LXII: 25-47.

Nelson, D.R., McCulloch, M.T. and Sun, S.S., 1986. The origins of ultrapotassic rocks as inferred from $\mathrm{Sr}$, $\mathrm{Nd}$ and $\mathrm{Pb}$ isotopes. Geochimica et Cosmochimica Acta, 50(2): 231-245.

Nelson, D.R., 1992. Isotopic characteristics of potassic rocks; evidence for the involvement of subducted sediments in magma genesis, Potassic and ultrapotassic magmas and their origin; Sixth meeting of the European Union of Geosciences (EUG VI). Elsevier, Amsterdam, International, pp. 403-420.

Obradovic, J., Djurdjevic, C.J., Vasic, N. and Grubin, N., 1994. Facies and characteristics of some Neogene lacustrine sediments in Serbia. Yanxiang Gudili = Sedimentary Facies and Palaeogeography, 14(4): 12-27.

Venturelli, G., Capedri, S., Battistini, G.D., Crawford, A., Kogarko, L. and Celestini, S., 1984a. The ultrapotassic rocks from southeastern Spain. Lithos, 17: 37-54.

Venturelli, G., Thorpe, R., Piaz, G.D., Moro, A.D. and Potts, P., 1984b. Petrogenesis of calk-alkaline, shoshonitic and associated ultrapotassic Oligocene volcanic rocks from the Northwestern Alps, Italy. Contributions to Mineralogy and Petrology, 86: 209-220.

Contact: Dejan Prelevic; Institut fuer Geologische Wissenschaften Universität Greifswald; F.-L. Jahnstrasse 17a; D-17487 Greifswald; Germany; E-mail: prelev@unigreifswald.de 